\title{
Evaluation of Undergraduate Orthodontic Courses at the Faculty of Dentistry in King Abdulaziz University
}

\author{
Fahad F. Alsulaimani, BDS, MS, DSc. \\ Department of Preventive Dental Science, Division of Orthodontics \\ Faculty of Dentistry, King Abdulaziz University \\ Jeddah, Saudi Arabia \\ falsulaimani@kau.edu.sa
}

\begin{abstract}
The undergraduate orthodontic courses at the Faculty of Dentistry, King Abdulaziz University are two and a half academic year, starting from the $4^{\text {th }}$ year with an introduction to orthodontics. During the $5^{\text {th }}$ year, students get exposed to different treatment modalities. During the $6^{\text {th }}$ and final year, students are exposed to clinical cases. The aim of this study was to evaluate the content of these courses, teaching techniques, and the importance of teaching orthodontics to the undergraduate students. Nineteen questions were distributed to the graduating class of 2011-12 (40 male and 55 females). The topics covered were: 1) the importance of orthodontic teaching to the undergraduate students, 2) the importance of the laboratory projects, 3) the teaching methods, and 4) the competency of the student after finishing the orthodontic courses. Answers were analyzed according to gender and final grades. Pearson's chi-squared test was used to evaluate significance. There was no significant difference between male and female in all of the 19 questions. When analyzing the data according to the final grades, there were also no significant differences in most of the questions. Most of the graduating students were satisfied with the content of the orthodontic courses.
\end{abstract}

Keywords: Orthodontic teaching, Orthodontic education, Undergraduate, King Abdulaziz University

Correspondence \& reprint request to: $\quad$ Dr. Fahad F. Alsulaimani

P.O. Box 80209, Jeddah 21589, Saudi Arabia

Accepted for publication: 26 September 2013. Received: 11 September 2013. 


\section{Introduction}

Orthodontics is one of the most popular specialties in dentistry ${ }^{[1]}$. The content of the undergraduate orthodontic courses in the dental schools is of great importance to qualify students with adequate knowledge to be able to recognize and deal with orthodontic problems appropriately.

The amount of orthodontic information given in the undergraduate curriculum in dental schools was studied by Noble et al. ${ }^{[2]}$ in 2009 . They found that $60 \%$ of the orthodontic residents in Canada had the right amount of orthodontics exposure in the dental school, while $36 \%$ of the residents did not have enough information ${ }^{[2]}$.

In recent years, there have been an alarming generalized opinion among colleagues in other dental specialties within dental schools that orthodontics is a postgraduate subject, and therefore it should not be taught at an undergraduate level ${ }^{[3]}$. Following the publication of the General Dental Council (GDC), The First Five Years (FFY), document ${ }^{[4]}$ in 2001; the second addition of the GDC stated "all dental students should be able to recognize and describe the developing occlusion and malocclusion and able to make an orthodontic assessment for the purpose of identifying and describing any manifest and developing malocclusion- whilst recognizing the significance, timing and likely outcome of such intervention" ${ }^{[5]}$. Misinterpretation has led to the report being cited as reason to justify further cuts to orthodontic course hours. Orthodontic undergraduate teaching courses are now under further pressure with the proposed increase in the numbers of undergraduate students, and further training programs for dentists with special interest in orthodontics and orthodontic therapists ${ }^{[4]}$. The last survey of undergraduate orthodontic teaching carried out in 1997 for the University Teachers Group of the British Orthodontic Society ${ }^{[2]}$, assessed only the total course hours, lecture, seminar, laboratory and clinical hours, and patient treatment numbers. In view of the radical changes in courses that have taken place in recent years, this survey is no longer up-to-date and lacks on many details of the course contents. A new survey giving current details of the content of each course, the changes that have taken place in the courses over the last three years, and future course developments is clearly needed.

Subsequently, there are no previous studies that evaluated undergraduate orthodontic courses by the students themselves as well as 
the overall with their undergraduate program. Therefore, the aim of this study was to assess the dental graduates' perception of the undergraduate orthodontic courses given at the Faculty of Dentistry at King Abdulaziz University in Jeddah.

\section{Materials and Method}

A set of 19 questions was developed to assess the importance of teaching orthodontics to the under graduate student at King Abdulaziz University Faculty of Dentistry (Table 1). The questionnaires were distributed to the graduating class (Dental Interns) who graduated during the academic year 2011-12. A total of 95 dental interns (40 males and 55 females) participated in this survey. Responses were checked for completeness, summarized and analyzed. The data was correlated to both gender and achieved grades. Chi-squared test was used to evaluate significant differences between the groups (genders) for each question.

Table 1. Summary of the 19 questions and comparisons of the response for male and female students.

\begin{tabular}{|c|c|c|c|c|c|c|}
\hline Question & Gender & Agree & Neutral & Disagree & Total & Significance \\
\hline \multirow{2}{*}{$\begin{array}{l}\text { 1. The Orthodontic course in the } 4 \text { th year } \\
\text { is important. }\end{array}$} & Male & $52.5 \%$ & $27.5 \%$ & $20.0 \%$ & $100 \%$ & \multirow{2}{*}{0.343} \\
\hline & Female & $54.5 \%$ & $16.4 \%$ & $29.1 \%$ & $100 \%$ & \\
\hline \multirow{2}{*}{$\begin{array}{l}\text { 2. The Orthodontic course in the } 5 \text { th year } \\
\text { is important }\end{array}$} & Male & $87.5 \%$ & $12.5 \%$ & $0 \%$ & $100 \%$ & \multirow{2}{*}{0.222} \\
\hline & Female & $94.5 \%$ & $5.5 \%$ & $0 \%$ & $100 \%$ & \\
\hline \multirow{2}{*}{$\begin{array}{l}\text { 3. The Orthodontic course in the } 6 \text { th year } \\
\text { is important }\end{array}$} & Male & $80 \%$ & $15 \%$ & $5 \%$ & $100 \%$ & \multirow{2}{*}{0.581} \\
\hline & Female & $76.4 \%$ & $12.7 \%$ & $10.9 \%$ & $100 \%$ & \\
\hline \multirow{2}{*}{$\begin{array}{l}\text { 4. The Orthodontics course should be } \\
\text { taught in the } 5 \text { th year only. }\end{array}$} & Male & $80.0 \%$ & $15 \%$ & $5.0 \%$ & $100 \%$ & \multirow{2}{*}{0.581} \\
\hline & Female & $76.4 \%$ & $12.7 \%$ & $10.9 \%$ & $100 \%$ & \\
\hline \multirow{2}{*}{$\begin{array}{l}\text { 5. The Orthodontics course should be } \\
\text { taught in the } 6 \text { th year only. }\end{array}$} & Male & $17.5 \%$ & $25.0 \%$ & $57.5 \%$ & $100 \%$ & \multirow{2}{*}{$0.023^{*}$} \\
\hline & Female & $10.9 \%$ & $7.3 \%$ & $81.8 \%$ & $100 \%$ & \\
\hline \multirow{2}{*}{$\begin{array}{l}\text { 6. Noting is learned from the } 5^{\text {th }} \text { year } \\
\text { laboratory class. }\end{array}$} & Male & $32.5 \%$ & $25.0 \%$ & $42.5 \%$ & $100 \%$ & \multirow{2}{*}{0.780} \\
\hline & Female & $30.9 \%$ & $20.0 \%$ & $49.1 \%$ & $100 \%$ & \\
\hline \multirow{2}{*}{$\begin{array}{l}\text { 7. The growth and development lectures } \\
\text { given in the } 4^{\text {th }} \text { year are important. }\end{array}$} & Male & $60.0 \%$ & $15 \%$ & $25.0 \%$ & $100 \%$ & \multirow{2}{*}{0.257} \\
\hline & Female & $52.7 \%$ & $29.1 \%$ & $18.2 \%$ & $100 \%$ & \\
\hline \multirow{2}{*}{$\begin{array}{l}\text { 8. The non-skeletal problems lectures } \\
\text { given in the } 5^{\text {th }} \text { year are important. }\end{array}$} & Male & $95.0 \%$ & $5.0 \%$ & $0 \%$ & $100 \%$ & \multirow{2}{*}{0.511} \\
\hline & Female & $89.1 \%$ & $9.1 \%$ & $1.8 \%$ & $100 \%$ & \\
\hline \multirow{2}{*}{$\begin{array}{l}\text { 9. The orthogenetic surgery lectures should } \\
\text { be given for master students not for } \\
\text { undergraduate students. }\end{array}$} & Male & $50.0 \%$ & $17.5 \%$ & $32.5 \%$ & $100 \%$ & \multirow{2}{*}{0.822} \\
\hline & Female & $56.4 \%$ & $14.5 \%$ & $29.1 \%$ & $100 \%$ & \\
\hline \multirow{2}{*}{$\begin{array}{l}\text { 10. The skeletal problems lectures given in } \\
\text { the } 5^{\text {th }} \text { year are important }\end{array}$} & Male & $92.5 \%$ & $7.5 \%$ & $0 \%$ & $100 \%$ & \multirow{2}{*}{0.351} \\
\hline & Female & $96.4 \%$ & $3.6 \%$ & $0 \%$ & $100 \%$ & \\
\hline
\end{tabular}


Table 1. (Continuation) Summary of the $\mathbf{1 9}$ questions and comparisons of the response for male and female students.

\begin{tabular}{|c|c|c|c|c|c|c|}
\hline Question & Gender & Agree & Neutral & Disagree & Total & Significance \\
\hline \multirow{2}{*}{$\begin{array}{l}\text { 11. Orthodontics teaching methods are } \\
\text { confusing. }\end{array}$} & Male & $45.0 \%$ & $35.0 \%$ & $20.0 \%$ & $100 \%$ & \multirow{2}{*}{0.881} \\
\hline & Female & $49.1 \%$ & $34.5 \%$ & $16.4 \%$ & $100 \%$ & \\
\hline \multirow{2}{*}{$\begin{array}{l}\text { 12. I did benefit from the clinical cases in the } \\
6^{\text {th }} \text { year CCC orthodontic class. }\end{array}$} & Male & $77.5 \%$ & $12.5 \%$ & $10.0 \%$ & $100 \%$ & \multirow{2}{*}{0.538} \\
\hline & Female & $70.9 \%$ & $10.9 \%$ & $18.2 \%$ & $100 \%$ & \\
\hline \multirow{2}{*}{$\begin{array}{l}\text { 13. Instead of the clinic in the } 6^{\text {th }} \text { year, a } \\
\text { complete case every week from the start to } \\
\text { finish covering all treatment modalities } \\
\text { will be more beneficial. }\end{array}$} & Male & $45.0 \%$ & $32.5 \%$ & $22.5 \%$ & $100 \%$ & \multirow{2}{*}{0.274} \\
\hline & Female & $54.5 \%$ & $18.2 \%$ & $27.3 \%$ & $100 \%$ & \\
\hline \multirow{2}{*}{$\begin{array}{l}\text { 14. After completing orthodontic courses, I am } \\
\text { confident that I can treat minor orthodontic } \\
\text { problem. }\end{array}$} & Male & $42.5 \%$ & $30.0 \%$ & $27.5 \%$ & $100 \%$ & \multirow{2}{*}{0.096} \\
\hline & Female & $32.7 \%$ & $18.2 \%$ & $49.1 \%$ & $100 \%$ & \\
\hline \multirow{2}{*}{$\begin{array}{l}\text { 15. The information given in the orthodontic } \\
\text { courses is too much. }\end{array}$} & Male & $57.5 \%$ & $20.0 \%$ & $22.5 \%$ & $100 \%$ & \multirow{2}{*}{$0.046^{*}$} \\
\hline & Female & $34.5 \%$ & $41.8 \%$ & $23.6 \%$ & $100 \%$ & \\
\hline \multirow{2}{*}{ 16. Orthodontic lectures are too long. } & Male & $32.5 \%$ & $45.0 \%$ & $22.5 \%$ & $100 \%$ & \multirow{2}{*}{$0.015 *$} \\
\hline & Female & $29.1 \%$ & $21.8 \%$ & $49.1 \%$ & $100 \%$ & \\
\hline \multirow{2}{*}{$\begin{array}{l}\text { 17. The instructors are giving too much } \\
\text { information during the lecture. }\end{array}$} & Male & $37.5 \%$ & $37.5 \%$ & $25.0 \%$ & $100 \%$ & \multirow{2}{*}{0.086} \\
\hline & Female & $27.2 \%$ & $25.5 \%$ & $47.3 \%$ & $100 \%$ & \\
\hline \multirow{2}{*}{$\begin{array}{l}\text { 18. After completing orthodontics classes, I } \\
\text { am confidant to diagnose most of the } \\
\text { orthodontic problems. }\end{array}$} & Male & $75.0 \%$ & $17.5 \%$ & $7.5 \%$ & $100 \%$ & \multirow{2}{*}{0.437} \\
\hline & Female & $67.2 \%$ & $16.4 \%$ & $16.4 \%$ & $100 \%$ & \\
\hline $\begin{array}{l}\text { 19. After completing the orthodontic courses, I } \\
\text { know when to refer cases to the } \\
\text { orthodontist. }\end{array}$ & Male & $90.0 \%$ & $7.5 \%$ & $2.5 \%$ & $100 \%$ & 0.728 \\
\hline
\end{tabular}

A total of 95 intern completed the questionnaires, 40 (42\%) males and $55(58 \%)$ females. The response was $100 \%$. In addition, the response to all 19 questions was also 100\%. Most resident (98\%) were in the range of 24 years of age. Table 1 showed the response of all interns based on gender. No significant difference was found between male and female interns except for questions 5, 15 and 16 . The significances were $0.023,0.046$ and 0.015 , respectively.

When correlating the response of the interns to their undergraduate grades as shown in Table 2. All the response was not statistically significant except for question 8 and 16. The significant level was 0.045 and 0.005 , respectively. 
Table 2. Responses to each question based on academic grades.

\begin{tabular}{|c|c|c|c|c|c|c|}
\hline Question & Grades & Agree & Neutral & Disagree & Total & Significance \\
\hline \multirow{4}{*}{$\begin{array}{l}\text { 1) The Orthodontic course in the } 4 \text { th } \\
\text { year is important. }\end{array}$} & A & $7.3 \%$ & $1.1 \%$ & $2.1 \%$ & $10.5 \%$ & \multirow{4}{*}{0.439} \\
\hline & B & $37.9 \%$ & $13.7 \%$ & $17.9 \%$ & $69.5 \%$ & \\
\hline & $\mathrm{C}$ & $8.4 \%$ & $6.3 \%$ & $4.2 \%$ & $18.9 \%$ & \\
\hline & $\mathrm{D}$ & $0.0 \%$ & $0.0 \%$ & $1.1 \%$ & $1.1 \%$ & \\
\hline \multirow[t]{4}{*}{ 2) } & $\mathrm{A}$ & $8.4 \%$ & $2.1 \%$ & $0 \%$ & $10.5 \%$ & \multirow{4}{*}{0.480} \\
\hline & B & $65.3 \%$ & $4.2 \%$ & $0 \%$ & $69.5 \%$ & \\
\hline & $\mathrm{C}$ & $16.8 \%$ & $2.1 \%$ & $0 \%$ & $18.9 \%$ & \\
\hline & $\mathrm{D}$ & $1.1 \%$ & $0.0 \%$ & $0 \%$ & $1.1 \%$ & \\
\hline \multirow[t]{4}{*}{ 3) 1} & A & $9.4 \%$ & $1.1 \%$ & $0.0 \%$ & $10.5 \%$ & \multirow{4}{*}{0.798} \\
\hline & B & $51.6 \%$ & $11.6 \%$ & $6.3 \%$ & $69.5 \%$ & \\
\hline & $\mathrm{C}$ & $15.8 \%$ & $1.1 \%$ & $2.1 \%$ & $18.9 \%$ & \\
\hline & $\mathrm{D}$ & $1.1 \%$ & $0.0 \%$ & $0.0 \%$ & $1.1 \%$ & \\
\hline \multirow[t]{4}{*}{ 4) $\mathrm{T}$} & A & $1.1 \%$ & $0.0 \%$ & $9.4 \%$ & $10.5 \%$ & \multirow{4}{*}{0.494} \\
\hline & B & $20.0 \%$ & $7.4 \%$ & $42.1 \%$ & $69.5 \%$ & \\
\hline & $\mathrm{C}$ & $6.2 \%$ & $3.2 \%$ & $9.5 \%$ & $18.9 \%$ & \\
\hline & $\mathrm{D}$ & $0.0 \%$ & $0.0 \%$ & $1.1 \%$ & $1.1 \%$ & \\
\hline \multirow[t]{4}{*}{ 5) 1} & A & $1.1 \%$ & $2.1 \%$ & $7.4 \%$ & $10.5 \%$ & \multirow{4}{*}{0.900} \\
\hline & B & $8.4 \%$ & $9.5 \%$ & $51.6 \%$ & $69.5 \%$ & \\
\hline & $\mathrm{C}$ & $4.2 \%$ & $3.2 \%$ & $11.6 \%$ & $18.9 \%$ & \\
\hline & $\mathrm{D}$ & $0.0 \%$ & $0.0 \%$ & $1.1 \%$ & $1.1 \%$ & \\
\hline \multirow{4}{*}{ 6) $\begin{array}{l}\mathrm{N} \\
\mathrm{y}\end{array}$} & A & $4.2 \%$ & $1.1 \%$ & $5.3 \%$ & $10.5 \%$ & \multirow{4}{*}{0.385} \\
\hline & B & $20.0 \%$ & $17.9 \%$ & $31.6 \%$ & $69.5 \%$ & \\
\hline & $\mathrm{C}$ & $7.4 \%$ & $2.1 \%$ & $9.5 \%$ & $18.9 \%$ & \\
\hline & $\mathrm{D}$ & $0.0 \%$ & $1.1 \%$ & $0.0 \%$ & 1.1 & \\
\hline \multirow[t]{4}{*}{ 7) 1} & A & $3.2 \%$ & $3.2 \%$ & $4.2 \%$ & $10.5 \%$ & \multirow{4}{*}{0.497} \\
\hline & B & $41.1 \%$ & $16.8 \%$ & $11.6 \%$ & $69.5 \%$ & \\
\hline & $\mathrm{C}$ & $10.5 \%$ & $3.2 \%$ & $5.3 \%$ & $18.9 \%$ & \\
\hline & $\mathrm{D}$ & $1.1 \%$ & $0.0 \%$ & $0.0 \%$ & $1.1 \%$ & \\
\hline \multirow{4}{*}{$\begin{array}{l}\text { The non-skeletal problems } \\
\text { lectures given in the } 5^{\text {th }} \text { year are } \\
\text { important. }\end{array}$} & A & $7.3 \%$ & $1.1 \%$ & $1.1 \%$ & $10.5 \%$ & \multirow{4}{*}{$0.045 *$} \\
\hline & $\mathrm{B}$ & $64.2 \%$ & $2.1 \%$ & $0.0 \%$ & $69.5 \%$ & \\
\hline & $\mathrm{C}$ & $18.9 \%$ & $5.3 \%$ & $0.0 \%$ & $18.9 \%$ & \\
\hline & $\mathrm{D}$ & $1.1 \%$ & $0.0 \%$ & $0.0 \%$ & $1.1 \%$ & \\
\hline \multirow{4}{*}{$\begin{array}{l}\text { The orthogenetic surgery lectures } \\
\text { should be given for master } \\
\text { students not for undergraduate } \\
\text { students. }\end{array}$} & A & $5.3 \%$ & $1.1 \%$ & $4.2 \%$ & $10.5 \%$ & \multirow{4}{*}{0.886} \\
\hline & B & $36.8 \%$ & $10.5 \%$ & $22.1 \%$ & $69.5 \%$ & \\
\hline & $\mathrm{C}$ & $10.5 \%$ & $4.2 \%$ & $4.2 \%$ & $18.9 \%$ & \\
\hline & $\mathrm{D}$ & $1.1 \%$ & $0.0 \%$ & $0.0 \%$ & $1.1 \%$ & \\
\hline 10) The skeletal problems lectures & A & $10.5 \%$ & $0.0 \%$ & $0.0 \%$ & $10.5 \%$ & \\
\hline given in the $5^{\text {th }}$ year are & B & $65.3 \%$ & $4.2 \%$ & $0.0 \%$ & $69.5 \%$ & 0.874 \\
\hline important & $\mathrm{C}$ & $17.9 \%$ & $1.1 \%$ & $0.0 \%$ & $18.9 \%$ & $0.8 / 4$ \\
\hline & $\mathrm{D}$ & $1.1 \%$ & $0.0 \%$ & $0.0 \%$ & $1.1 \%$ & \\
\hline 11) Orthodontics teaching methods & A & $6.3 \%$ & $2.1 \%$ & $2.1 \%$ & $10.5 \%$ & \\
\hline are confusing. & $\mathrm{B}$ & $29.5 \%$ & $27.4 \%$ & $12.6 \%$ & $69.5 \%$ & \\
\hline & $\mathrm{C}$ & $11.6 \%$ & $4.2 \%$ & $3.2 \%$ & $18.9 \%$ & 0.523 \\
\hline & $\mathrm{D}$ & $0.0 \%$ & $1.1 \%$ & $0.0 \%$ & $1.1 \%$ & \\
\hline 12) I did benefit from the clinical & A & $9.4 \%$ & $1.1 \%$ & $0.0 \%$ & $10.5 \%$ & \\
\hline cases in the $6^{\text {th }}$ year CCC & B & $48.4 \%$ & $8.4 \%$ & $12.6 \%$ & $69.5 \%$ & 0705 \\
\hline orthodontic class. & $\mathrm{C}$ & $14.7 \%$ & $2.1 \%$ & $2.1 \%$ & $18.9 \%$ & 0.795 \\
\hline & $\mathrm{D}$ & $.1 .1 \%$ & $0.0 \%$ & $0.0 \%$ & $1.1 \%$ & \\
\hline
\end{tabular}


Table 2. (Continuation) Responses to each question based on academic grades.

\begin{tabular}{|c|c|c|c|c|c|c|c|}
\hline & Question & Grades & Agree & Neutral & Disagree & Total & Significance \\
\hline \multirow[t]{4}{*}{ 13) } & \multirow{4}{*}{$\begin{array}{l}\text { Instead of the clinic in the } 6^{\text {th }} \\
\text { year, a complete case every week } \\
\text { from the start to finish covering } \\
\text { all treatment modalities will be } \\
\text { more beneficial. }\end{array}$} & $\mathrm{A}$ & $5.3 \%$ & $0.0 \%$ & $5.2 \%$ & $10.5 \%$ & \multirow{4}{*}{0.273} \\
\hline & & $\mathrm{B}$ & $36.8 \%$ & $17.9 \%$ & $14.7 \%$ & $69.5 \%$ & \\
\hline & & $\mathrm{C}$ & $7.4 \%$ & $6.3 \%$ & $5.3 \%$ & $18.9 \%$ & \\
\hline & & $\mathrm{D}$ & $1.1 \%$ & $0.0 \%$ & $0.0 \%$ & $1.1 \%$ & \\
\hline \multirow[t]{4}{*}{ 14) } & \multirow{4}{*}{$\begin{array}{l}\text { After completing orthodontic } \\
\text { courses, I am confident that I can } \\
\text { treat minor orthodontic problem. }\end{array}$} & $\mathrm{A}$ & $3.2 \%$ & $2.1 \%$ & $5.3 \%$ & $10.5 \%$ & \multirow{4}{*}{0.509} \\
\hline & & B & $27.4 \%$ & $13.7 \%$ & $28.4 \%$ & $69.5 \%$ & \\
\hline & & $\mathrm{C}$ & $6.3 \%$ & $6.3 \%$ & $6.3 \%$ & $18.9 \%$ & \\
\hline & & $\mathrm{D}$ & $0.0 \%$ & $1.1 \%$ & $0.0 \%$ & $1.1 \%$ & \\
\hline \multirow[t]{4}{*}{ 15) } & \multirow{4}{*}{$\begin{array}{l}\text { The information given in the } \\
\text { orthodontic courses is too much. }\end{array}$} & A & $5.3 \%$ & $2.1 \%$ & $3.2 \%$ & $10.5 \%$ & \multirow{4}{*}{$0.005^{*}$} \\
\hline & & B & $23.2 \%$ & $28.4 \%$ & $17.9 \%$ & $69.5 \%$ & \\
\hline & & $\mathrm{C}$ & $15.8 \%$ & $2.1 \%$ & $1.1 \%$ & $18.9 \%$ & \\
\hline & & $\mathrm{D}$ & $0.0 \%$ & $0.0 \%$ & $1.1 \%$ & $1.1 \%$ & \\
\hline \multirow[t]{4}{*}{ 16) } & \multirow{4}{*}{$\begin{array}{l}\text { Orthodontic lectures are too } \\
\text { long. }\end{array}$} & A & $3.2 \%$ & $2.1 \%$ & $5.3 \%$ & $10.5 \%$ & \multirow{4}{*}{0.377} \\
\hline & & $\mathrm{B}$ & $18.9 \%$ & $22.1 \%$ & $28.4 \%$ & $69.5 \%$ & \\
\hline & & $\mathrm{C}$ & $8.4 \%$ & $7.4 \%$ & $3.2 \%$ & $18.9 \%$ & \\
\hline & & $\mathrm{D}$ & $0.0 \%$ & $0.0 \%$ & $1.1 \%$ & $1.1 \%$ & \\
\hline \multirow[t]{4}{*}{ 17) } & \multirow{4}{*}{$\begin{array}{l}\text { The instructors are giving too } \\
\text { much information during the } \\
\text { lecture. }\end{array}$} & A & $3.2 \%$ & $4.2 \%$ & $3.2 \%$ & $10.5 \%$ & \multirow{4}{*}{0.054} \\
\hline & & B & $16.8 \%$ & $21.1 \%$ & $31.6 \%$ & $69.5 \%$ & \\
\hline & & $\mathrm{C}$ & $11.6 \%$ & $4.2 \%$ & $3.2 \%$ & $18.9 \%$ & \\
\hline & & $\mathrm{D}$ & $0.0 \%$ & $1.1 \%$ & $0.0 \%$ & 1.1 & \\
\hline \multirow[t]{4}{*}{ 18) } & \multirow{4}{*}{$\begin{array}{l}\text { After completing orthodontics } \\
\text { classes, I am confidant to } \\
\text { diagnose most of the orthodontic } \\
\text { problems. }\end{array}$} & $\mathrm{A}$ & $7.3 \%$ & $2.1 \%$ & $1.1 \%$ & $10.5 \%$ & \multirow{4}{*}{0.982} \\
\hline & & $\mathrm{B}$ & $49.5 \%$ & $10.5 \%$ & $9.5 \%$ & $69.5 \%$ & \\
\hline & & $\mathrm{C}$ & $12.6 \%$ & $4.2 \%$ & $2.1 \%$ & $18.9 \%$ & \\
\hline & & $\mathrm{D}$ & $1.1 \%$ & $0.0 \%$ & $0.0 \%$ & $1.1 \%$ & \\
\hline \multirow[t]{4}{*}{ 19) } & \multirow{4}{*}{$\begin{array}{l}\text { After completing the orthodontic } \\
\text { courses, I know when to refer } \\
\text { cases to the orthodontist. }\end{array}$} & $\mathrm{A}$ & $10.5 \%$ & $0.0 \%$ & $0.0 \%$ & $10.5 \%$ & \multirow{4}{*}{0.774} \\
\hline & & B & $61.1 \%$ & $4.2 \%$ & $4.2 \%$ & $69.5 \%$ & \\
\hline & & $\mathrm{C}$ & $16.8 \%$ & $2.1 \%$ & $0.0 \%$ & $18.9 \%$ & \\
\hline & & $\mathrm{D}$ & $1.1 \%$ & $0.0 \%$ & $0.0 \%$ & $1.1 \%$ & \\
\hline
\end{tabular}

\section{Discussion}

Most dental schools try to evaluate their undergraduate programs in all disciplines to prepare their graduates with the necessary information, both theoretical and practical. This study was constructed to help evaluate the undergraduate orthodontic courses to help develop them to a contemporary level.

Other orthodontic programs in their quest to evaluate their orthodontic teachings for the undergraduate, postgraduate and containing education level $^{[5]}$, found that most of the European countries have difficulties in the undergraduate program because of the funding, and in the post graduate programs and the continuing education progress due to the lack of teachers ${ }^{[1]}$. However, this is not the case in our undergraduate 
courses, the data shows that the students are getting enough education and have enough teachers, and getting the required material to attain the adequate educational level. Furthermore, the undergraduate orthodontic course at King Abdulaziz University is a two and a half year course, which is similar to most of the dental school curriculum in the United Kingdom $^{[3]}$.

The results of this study showed that there is an agreement between males and females regarding the importance of the $5^{\text {th }}$ and $6^{\text {th }}$ year orthodontic courses $(90 \%$ and $80 \%$, respectively). This could be due to fact that the students are exposed to most of the orthodontic problems during the lectures or at the clinical session. In the $4^{\text {th }}$ year about one half of the students agreed on its importance, and when analyzed the ones who did agree, it was found that most of them scored A and B in the grades.

Although some students are getting the benefit from the $4^{\text {th }}$ year lectures, more than one half are not, and due to the increase in number of enrolled students, the school, recently, decided to discontinue the $4^{\text {th }}$ year's orthodontic course. This is similar to what transpired in most of the programs in the United Kingdom due to funding and lack of teachers and an increase in the number of students ${ }^{[3,6]}$.

Regarding limiting the curriculum to $5^{\text {th }}$ year only, the response of the majority of interns was to limit the course to the $5^{\text {th }}$ year only. One explanation is that a limited number will pursue postgraduate studies in orthodontics.

Regarding the laboratory work during the $5^{\text {th }}$ year, most of the student did not like the laboratory work and they believed that they did not learn from it. Our finding supports the data from Derringer work ${ }^{[6]}$, where four of the dental schools in UK did cancel the laboratory work hours which were reduced from 60 to 9 hours in total ${ }^{[3]}$.

There was a lot of conflict in teaching methods among student. Several studies tried to find the best teaching method for the undergraduate. They tried the e-learning ${ }^{[7]}$ and Computer Assisted Learning $(\mathrm{CAL})^{[8-10]}$. The outcome of all these studies was that there is no best way of teaching. Some authors believe the conventional method of teaching is the best and some think the CAL is better ${ }^{[8,9]}$. While 
Linjawi et al. believes that e-learning is supplement to the conventional method $^{[7]}$.

Retrouvery and Finkelstein ${ }^{[10]}$ gave an idea about the interactive orthodontic course for the undergraduate students and assessed its acceptance. Their finding was that after 5 years of use at McGill University, the interactive orthodontic computer program has been well received by the student, and seems to offer an interactive and successful method for learning the complexity of the orthodontic discipline ${ }^{[10]}$.

Rosenberg et al. ${ }^{[11]}$ reviewed four studies of Computer-Assisted Learning (CAL) in orthodontic teaching and reported conflicting results. Clark et $a l^{[12]}$ identified no significant difference between the two methods of learning, whereas Irvine and Moore ${ }^{[13]}$ and Luffingham ${ }^{[8]}$ reported a significant advantage for CAL over conventional methods. In contrast, Hobson et al. ${ }^{[14]}$ reported a superior effect using conventional methods.

The data from the present study showed that almost half of the male interns and close to third of the female interns were confident to treat minor orthodontic cases. This could be due to the extensive amount of information given to the student during their undergraduate courses. In addition, the data support the work of Noble et al. ${ }^{[2]}$, where they found that about of $87 \%$ of the Canadian orthodontic residents are ready to enter the workforce after graduation, while $14 \%$ were not sure ${ }^{[2]}$.

No agreement was seen between genders regarding the amount of information given in the lecture. About one third of the students believed it is long where one third was neutral and the rest disagreed.

Most of the students above $70 \%$ were confident to diagnose orthodontic problems and can refer the patient to the orthodontist in contrast to the findings of Noble and colleagues ${ }^{[2]}$. In addition, the finding of this study was in concert with the philosophy that is adopted by the Newcastle undergraduate orthodontic ${ }^{[14]}$.

The limitation of this study is that the results are based on one graduating class, and cannot be applied to all KAU graduates. Further studies are required that incorporate similar questions to graduating classes from different years to confirm the current results. 


\section{Conclusions}

In this survey the response rate is $100 \%$ which is excellent and reflects the opinion of all intern students. The response to questions from the interns was anonymous, this was to ensure comfort to the interns and reflect the interns perspectives. Overall, the majority of the intern reported satisfaction with their undergraduate teaching of orthodontic courses. The data indicated that the students sufficient theoretical and clinical exposure in their undergraduate orthodontic course. This study also provides valuable information about perception of the interns about the entire orthodontic course and the method of teaching.

\section{Acknowledgments}

I thank Dr. Asim Almarhomi for his assistance during the course of the study.

\section{References}

[1] ADA Survey Center. 2003/2004 survey of advanced dental education. Chicago: American Dental Association, 2005.

[2] Noble J, Hechter FJ, Karaiskos NE, Wiltshire WA. Resident evaluation of orthodontic programs in Canada. J Dent Educ 2009; 73(2): 192-198.

[3] Derringer KA. Undergraduate orthodontic teaching in UK dental schools. Br Dent J 2005; 199(4): 224-232.

[4] General Dental Council. The first five-year: A framework for undergraduate education 1997.

[5] General Dental Council. The first five-year: A framework for undergraduate education. 2nd ed. 2001.

[6] Sieminska-Piekarczyk B, Adamidis JP, Eaton KA, McDonald JP, Seeholzer H. A survey of perceived problems in orthodontic education in 23 European countries. J Orthod 2000; 27(4): 343-348.

[7] Linjawi AL, Hamdan AM, Perryer DG, Walmsley AD, Hill KB. Students' attitudes towards an on-line orthodontic learning resource. Eur J Dent Educ 2009; 13(2): 87-92.

[8] Luffingham JK. An assessment of computer-assisted learning in orthodontics. Br J Orthod 1984; 11(4): 205-208.

[9] Schittek M, Mattheos N, Lyon HC, Attstrom R. Computer assisted learning. A review. Eur J Dent Educ 2001; 5(3): 93-100.

[10] Retrouvey JM, Finkelstein AB. Blended learning in orthodontic diagnosis: an interactive approach. J Can Dent Assoc 2008; 74(7): 645-649.

[11] Rosenberg H, Grad HA, Matear DW. The effectiveness of computer-aided, selfinstructional programs in dental education: a systematic review of the literature. $J$ Dent Educ 2003; 67(5): 524-532. 
[12] Clark RD, Weekrakone S, Rock WP. A Hypertext tutorial for teaching cephalometrics. Br J Orthod 1997; 24(4): 325-328.

[13] Irvine NR, Moore RN. Computer-assisted instruction in mixed dentition analysis. $J$ Dent Educ 1986; 50(6): 312-315.

[14] Hobson RS, Carter NE, Hall FM, Atkins MJ. A study into the effectiveness of a textbased computer-assisted learning program in comparison with seminar teaching of orthodontics. Eur J Dent Educ 1998; 2(4): 154-159. 


\title{
تقييم منهج تقويم الأسنان بكلية طب الأسنان في جامعة الملك

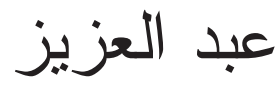

\author{
فهائز السليماني \\ قفم طب الأسنان الوقائي، كلية طب الأسنان، \\ جامعة الملك عبد العزبز \\ جدة - المدلكة العربية السعودية
}

المستخلص. أجريت هذه الدراسة لتقييم منهج تقويم الأسنان مـن

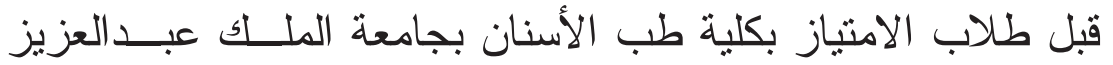

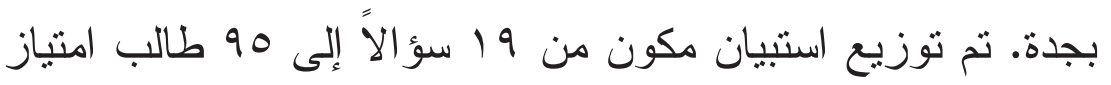
(0) ذكر و 00 أنثى) بكلية طب الأسنان جامعة الملك عبــــالعزيز بجدة. حيث تحتوي الأسئلة على أهمية تدريس مادة تقويم الأســنان

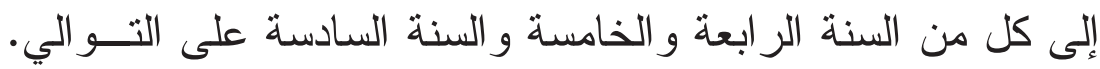
كما تحتوي على أهمية وجود العملي في السنة الر ابعة و الخامسسة.

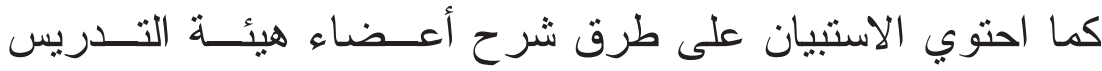

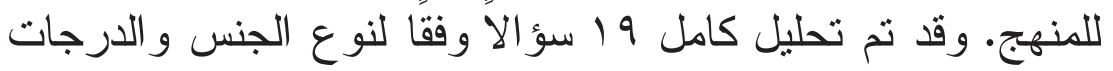

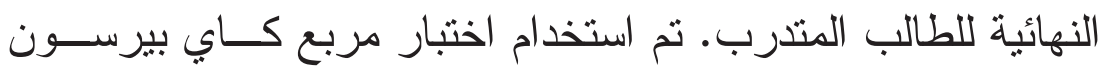
لتقييم الأهمية. 